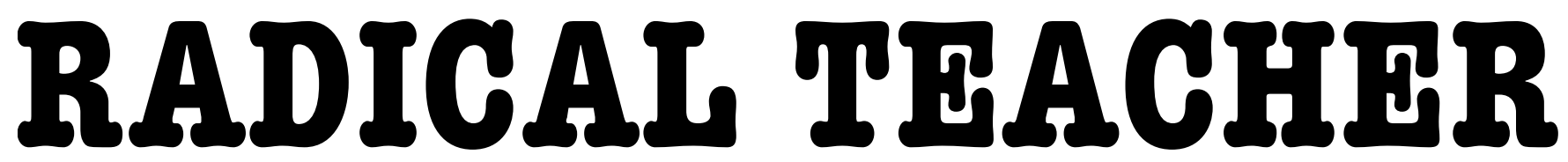
A SOCIALIST, FEMINIST, AND ANTI-RACIST JOURNAL ON THE THEORY AND PRACTICE OF TEACHING

Review: Will College Pay Off?: A Guide to the Most Important Financial Decision You'll Ever Make by Peter Cappelli

Reviewed by Nicole Hala

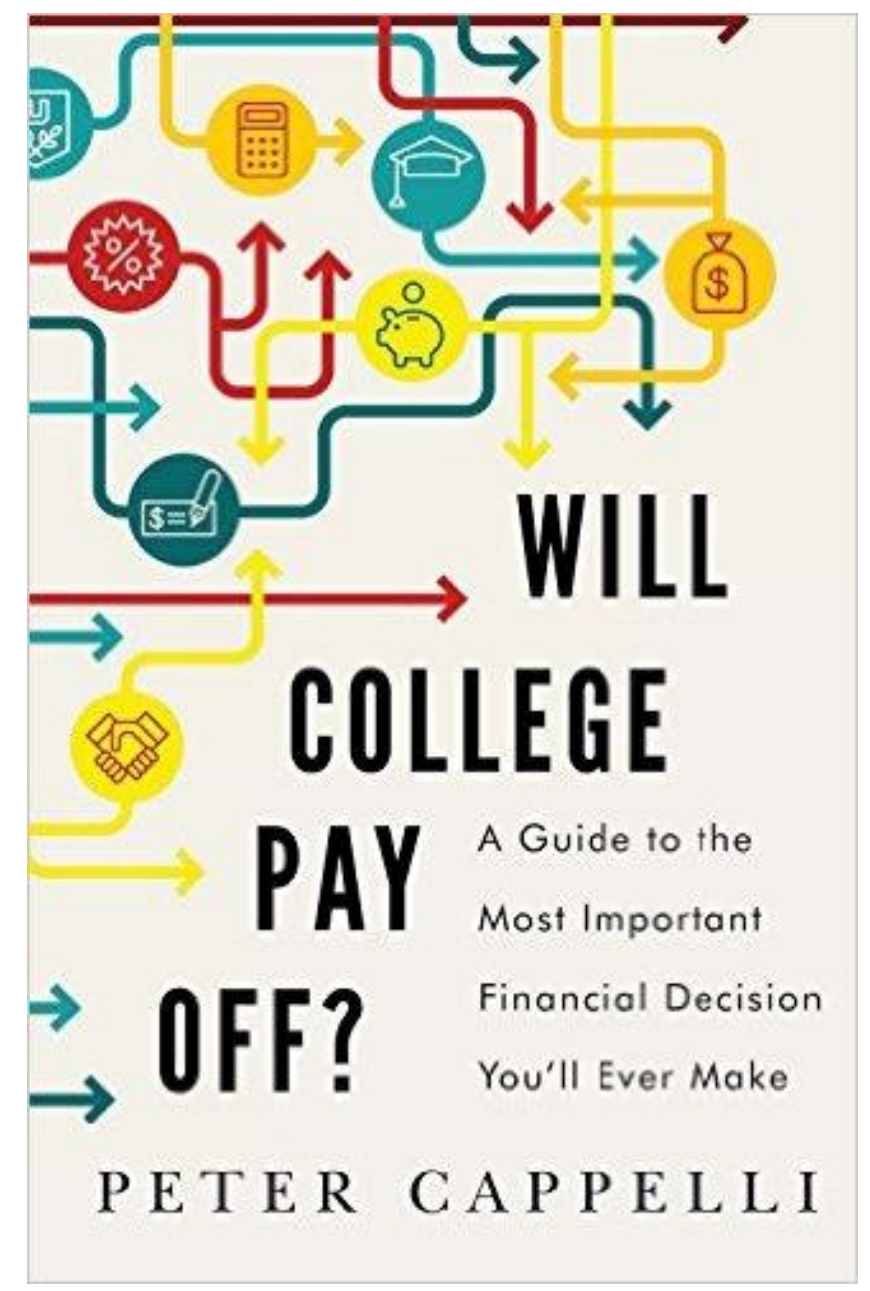




\section{Will College Pay Off?: A Guide to the Most Important Financial Decision You'll Ever Make (PublicAffairs, 2015)by Peter Cappelli}

\section{Reviewed by Nicole Hala}

It seems almost un-American to question the value of a college degree. Liberals and conservatives alike tout postsecondary education as a cure for poverty, a weapon against inequality, and the primary means of upward mobility in society today. For decades, we have been hearing about the "wage gap" between college and high school graduates, the sizeable income "premium" that accrues to those with college degrees. Since the start of the Great Recession, we have seen an "employment gap," with less educated workers suffering higher rates of unemployment, for longer periods. According to the latest headlines, the divergence is greater among Millennials than previous generations, suggesting that the college payoff is only getting bigger.

Propelled by hope of rising or by fear of falling, more than 70 percent of U.S. high school graduates go on to college (6). The United States leads the world in college enrollment, which totals 21 million, a number that has risen by 50 percent since the mid-1990s (176). While enrollments have surged, public funding for higher education has not kept pace, pushing a greater share of the costs onto students and their families, who pay six times as much as their peers in other developed countries (115). Over the past 30 years, the real cost of tuition and fees has increased more than virtually all other prices: 250 percent at private colleges and a stunning 330 percent at underfunded public institutions (118-9), which enroll about 80 percent of students (55). Over the same period, incomes have stagnated. The enrollment surge since the mid-1990s is disproportionately from families who are not wealthy, whose real incomes have been falling, and whose savings are meager (176). Yet new financing options have enabled cash-strapped families to borrow against their homes and retirement savings in order to send their kids to college. How could they refuse, when the payoff seems like such a sure thing?

Concerned by the irrational exuberance about the college payoff, Wharton management professor Peter Cappelli urges families to exercise due diligence before making an investment that can lead to financial ruin. An expert in employment trends, the workforce, and education, Cappelli has spent years studying the school-towork transition. His latest book, Will College Pay Off?: A Guide to the Most Important Financial Decision You'll Ever Make (2015), sheds light on the factors that determine whether a particular program will pay off, separating college myths from college realities. While much of the national discussion fixates on rewards, this clear, comprehensible guide is dedicated to helping students and families understand and manage the considerable risks of the college investment.

The wage gap or "college premium"-i.e., the additional average income a college graduate earns relative to a high school graduate-is often presented as conclusive evidence of the college payoff. Cappelli, however, calls attention to the tremendous variation in graduates' earnings across schools and across fields. Using the average earnings of all graduates to decide whether to go to college, he says, "would be like using the average temperature of the earth . . . to decide whether to wear a coat today" (103).

\section{Since the Great Recession, new college graduates have struggled to find gainful employment on secure career paths. "Skills mismatch" is the common explanation, which assigns blame to students and colleges, implying that employment security is simply a matter of getting the right degree.}

The most interesting point about the wage gap, according to Cappelli, is how much it has changed over time. The college premium, which today is likened to an economic law, was virtually nonexistent in the early 1960s and again in the late 1970s, when high school dropouts, high school grads and college grads had similar weekly earnings (90). That changed after the 1981 recession, which started the collapse of real wages for everyone with less than a four-year degree. Pay continued to fall through the early 1990s, thanks to deunionization, especially in the manufacturing sector, and low-wage competition from China. Wages for college graduates recovered, but they did not exactly take off. Cappelli points out that the improved college premium is mainly the result of the decline in earnings for non-grads: "Suddenly it paid to have a college degree because the wages if you didn't have one were awful" (90). (Yet, even today, this is not a universal rule; in China and Italy, for example, there is no college premium, as college grads have a harder time finding jobs than do high school grads (95).)

Since the Great Recession, new college graduates have struggled to find gainful employment on secure career paths. "Skills mismatch" is the common explanation, which assigns blame to students and colleges, implying that employment security is simply a matter of getting the right degree. In response, collegesparticularly, for-profit colleges-have shifted toward programs promising skills training that leads to jobs at graduation. Disputing claims of skills shortage, Cappelli argues that such narrow vocational degrees are risky investments in an increasingly unpredictable job market, especially when they involve loans, as for-profit degrees nearly always do. Locking students into occupations years before they graduate, these narrowly focused degrees make it difficult to do anything else should graduates fail to 
find jobs in their fields. Graduates of for-profit schoolswhere the graduation rate is only 22 percent-are further burdened by outsized debt; for-profits enroll ten percent of all students but account for 40 percent of defaults (Larson 2016). Cappelli's point is not that there is a big financial payoff to a liberal arts degree, but that "there is no guarantee of a payoff from very practical, work-based degrees either, yet that is all those degrees promise." Liberal arts offer something else, he says: "to enrich your life and provide lessons that extend beyond any individual job" (27).

So will college pay off? "Not necessarily," Cappelli concludes. "It depends on who you are and where you go." The return from many programs-as much as one in four, he estimates-is actually negative. Yet, even here, Cappelli refrains from any kind of structural analysis, instead adding that "Much of the problem may have to do with the attributes of the students attending those schools" (179-180). Structural inequities (e.g., class and race) are conceptualized strictly as individual attributes. The "limits of schooling" are similarly emphasized with respect to the mythic college premium, which may have less to do with what happens in college than with preexisting advantages that got college graduates admitted in the first place, according to Cappelli: "Some of those advantages have to do with abilities, some with family background and resources that would have allowed them to do better in life even if they did not go to college" (179). In fact, the United States ranks nearly last among industrial countries in upward mobility, as measured by the percentage of college students whose parents did not attend college, a staggering statistic the book mentions in passing (61).

\section{For most members of disadvantaged communities, however, investing in college will not pay off and may leave them worse off-deeply in debt, with no degree to show for it.}

The book cites numerous similar studies, all the latest data, international and longitudinal, conjuring up-for readers attuned to issues of educational equity, at least-a system of higher education that is highly stratified and tends to reinforce rather than reduce inequality. For Cappelli's intended readers, however, the data is meant to serve a more narrow, specific purpose: to guide investment. As a response to the college funding crisis, financial literacy education can empower individual consumers, but may also serve to justify further austerity and the ongoing neoliberalization of higher education (Arthur 2012).

"College graduates" are more diverse than ever, and so is the "college experience," rendering "average" outcomes largely meaningless. Long focused on the differences between college grads and non-grads, researchers have turned their attention to differences within the college-educated group, finding significant and systematic variation in outcomes-by class background, family income, race/ethnicity, etc. (Hershbein 2016; Emmons \& Noeth 2015; Mettler 2014; Glass \& Nygreen 2011). Specifying the critical trends shaping the college payoff, Cappelli helps explain why. Stagnating incomes, public funding cutbacks, escalating college costs, rising levels of student loan debt, declining graduation rates, lengthening time-to-degree, shifts in the structure of financial aid (favoring merit over need and loans over grants) and other related trends have had disproportionately negative effects on low-income, minority, and first-generation college students.

Thus, the groups that most need a payoff from college can expect the least benefit-on average, that is. Yes, some disadvantaged students can beat the odds, and guidebooks like this can help them do so. For most members of disadvantaged communities, however, investing in college will not pay off and may leave them worse off-deeply in debt, with no degree to show for it. For decades, we have relied on education to solve the problems of poverty, economic inequality, and racial injustice, an indirect approach meant to work by equalizing opportunity. But education, as the apparent need for Cappelli's guidebook makes clear, is not equalizing opportunity. To improve the lives of disadvantaged individuals and communities requires investing in programs and policies that confront structural inequities head-on.

\section{Works Cited}

Arthur, Chris. Financial Literacy Education:

Neoliberalism, the Consumer and the Citizen.

Rotterdam: Sense Publishers, 2012. Print.

Cappelli, Peter. Will College Pay Off?: A Guide to the

Most Important Financial Decision You'll Ever Make.

New York: PublicAffairs, 2015. Print.

Emmons, William R. and Bryan J. Noeth. "Why Didn't

Higher Education Protect Hispanic and Black

Wealth? " In the Balance. Federal Reserve Bank of

St. Louis, Issue 12 2015. Web. 3 June 2016.

Glass, Ronald David and Kysa Nygreen. "Class, Race, and the Discourse of 'College for All'." Democracy \&

Education. 19.1 (2011): 1-8. Web. 1 July 2014. 
Hershbein, Brad. "A College Degree is Worth Less if You Are Raised Poor. " Brookings. Social Mobility Memos, 19 Feb. 2016. Web. 3 June 2016.

Larson, Ann. “Obama's missed chance to help forprofit college students." Politico, 6 June 2016. Web.

26 June 2016.

Mettler, Suzanne. Degrees of Inequality: How the

Politics of Higher Education Sabotaged the
American Dream. New York: Basic Books, 2014.

Print.
This work is licensed under a Creative Commons Attribution-Noncommercial-No Derivative Works 3.0 United States License.

This journal is published by the University Library System of the University of Pittsburgh as part of its D-Scribe Digital Publishing Program, and is cosponsored by the University of Pittsburgh Press. 